\title{
Rapid changes in the epifaunal community after detachment of buoyant benthic macroalgae
}

\author{
L. GUTOW ${ }^{1}$, L. GIMÉNEZ ${ }^{2}$, K. BOOS ${ }^{3}$ AND R. SABOROWSKI ${ }^{3}$ \\ ${ }^{1}$ Alfred Wegener Institute for Polar and Marine Research, Box 1201 61, 27515 Bremerhaven, Germany, ${ }^{2}$ School of Ocean Sciences, \\ University of Wales, Bangor, Menai Bridge, Anglesey, LL59 5AB, UK, ${ }^{3}$ Biologische Anstalt Helgoland, Foundation Alfred Wegener \\ Institute for Polar and Marine Research, Marine Station, Box 180, 27483 Helgoland, Germany
}

\begin{abstract}
Rafting on floating macroalgae is a common dispersal mechanism of marine benthic invertebrates. Most benthic macroalgae are inhabited by diverse epifaunal communities but not all organisms may be adapted to live on floating algae. In particular, knowledge about the immediate effects of algal detachment on the associated biota is limited. Herein, we studied the composition of the communities of mobile invertebrates on benthic thalli of Ascophyllum nodosum and compared it with detached thalli that had floated for short periods. The community of the mobile invertebrates changed significantly within the first minute after detachment of the algae and showed decreased diversity and a tendency towards reduced abundances in most taxa. However, during the subsequent two hours of floating at the sea surface the species composition did not change further. A comparison of the size-spectra of the gastropod Littorina obtusata from attached and detached algae did not reveal differential migratory activity among size-classes of these gastropods. Most of the species encountered in this study are common rafters in coastal and offshore waters, which are well capable of holding onto floating seaweeds. Therefore, our results indicate that the animals actively abandoned the macroalgae immediately after detachment. A benefit of this behaviour may be to avoid increased predation risk in the open water. The fact that individuals remain associated with their algal host after detachment indicates the importance of rafting dispersal for a great variety of phytal species that might lead to range expansion and regional population persistence through metapopulation effects.
\end{abstract}

Keywords: active migration, passive dispersal, phytal invetebrates, rafting

Submitted 7 February 2008; accepted 23 July 2008; first published online 17 November 2008

\section{INTRDロUCTIDN}

Rafting on objects which are floating at the sea surface is a common mechanism for the dispersal of marine species. Rafting dispersal is supported by a great variety of natural and anthropogenic floating items in the world's oceans. The most common floating objects in temperate waters are buoyant macroalgae (Thiel \& Gutow, 2005a, b). Many seaweed species (mainly Phaeophyceae) possess pneumatocysts that keep submerged algal fronds in an upright position and allow them to float after detachment. When detached from their substratum by wave action (Seymour et al., 1989), herbivorous feeding activity (Duggins et al., 2001), or as a natural event in the alga's life cycle (Thomsen et al., 2004) buoyant macroalgae rise up to the sea surface and carry with them a diverse epifaunal community from the benthic habitat.

The associated organisms can experience severe changes in their living conditions after detachment of their benthic algal substratum. Pressure and light conditions change during the ascent to the sea surface. At the surface, organisms are exposed to harmful UV-radiation and strong temperature

Corresponding author:

L. Gutow

Email: Lars.Gutow@awi.de fluctuations (Cheng, 1975). Floating patches of macroalgae attract seabirds and predatory fish that forage intensively on associated organisms (Vandendriessche et al., 2007a, b). Many algae are washed onto nearby shores quickly after detachment (Harrold \& Lisin, 1989). While sessile epifaunal organisms are unable to leave their algal substratum mobile animals can rapidly abandon detached macroalgae. Kingsford \& Choat (1985) observed that invertebrates streamed off and fish darted away from the plants as they began their ascent'. Caprellid amphipods have been seen to leave detached Sargassum sp. and descend back to the sea floor when the algae started to float (Takeuchi \& Sawamoto, 1998). Boring limnorid isopods quickly leave their holdfast burrows after experimental detachment of kelp holdfasts from the benthic substratum (Miranda \& Thiel, 2008). Based on reports of low numbers of echinoderms, decapod crustaceans and gastropods on detached algae (Kingsford \& Choat, 1985), Thiel \& Gutow (2005b) suggested that particularly large organisms fall off quickly due to their incapability of holding onto floating objects. As a consequence, total densities of epifaunal invertebrates on macroalgae may significantly decrease during the first few minutes after detachment (Kingsford \& Choat, 1985) resulting in substantial changes in the composition of the epifaunal community.

The composition of rafting communities on macroalgae collected from the sea surface after extended floating periods 
has been studied by Stoner \& Greening (1984), Hobday (2000) and Tsikhon-Lukanina et al. (2001). Similarly, experimental investigations have focused on later successional stages of the rafting community on detached and tethered macroalgae that had been suspended in the water column or at the sea surface for weeks to months (Edgar, 1987; Vásquez, 1993; Ingólfsson, 1998). However, there is a lack of knowledge about changes in the epifaunal community of macroalgae immediately after detachment. We, therefore, investigated the immediate effects of algal detachment on the composition of the mobile epifauna in an intertidal kelp bed at the southwest coast of Iceland. We hypothesized that substantial changes in the rafting community occur immediately after algal detachment. In order to test whether particular sizeclasses or life history stages react to the detachment of their algal host, the size spectra of a common rafter on macroalgae in waters around Iceland, the gastropod Littorina obtusata, were compared between attached and floating macroalgae.

\section{MATERIALS AND METHDDS}

Experiments were carried out in August 2004 on two successive days of calm weather in the intertidal at the Sandgerði Marine Station located at the exposed west coast of Reykjanes peninsula (south-western Iceland). The sandy intertidal at Sandgerði is interspersed with extensive rocky lava fields (Figure 1) covered by dense canopies of fucoid brown algae, mainly Ascophyllum nodosum (L.) Le Jol. 1863. According to Espinosa \& Guerra-García (2005) the study site is largely controlled by natural biological and physical factors without significant effects of pollution. The tides around Iceland are semi-diurnal (Anonymous, 1993 cited in Ingólfsson 1996) and the tidal range at the south and southwest coast varies between 2.5 and $3.8 \mathrm{~m}$ (Ingólfsson, 1996). Water temperatures during the study period were about $12^{\circ} \mathrm{C}$ (data kindly provided by Heðinn Valdimarsson, Marine Research Institute, Reykjavik).

Randomly chosen complete thalli of the brown alga A. nodosum were cautiously detached from their rocky substratum in about $1.5 \mathrm{~m}$ depth by a person standing in the

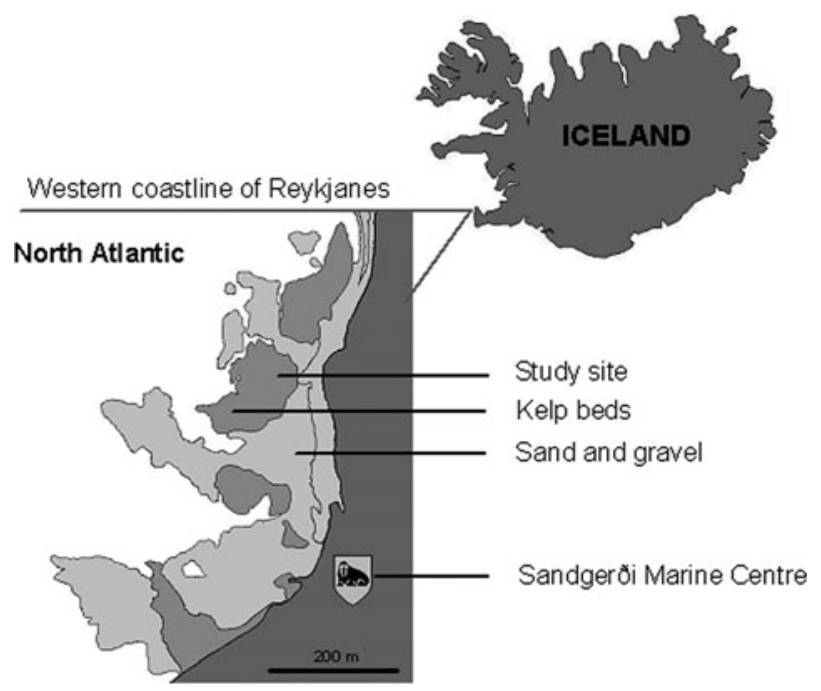

Fig. 1. Structure of the coast and location of the intertidal study site at Sandgerði on the west coast of Reykjanes peninsula (south-western Iceland). submerged kelp bed. Each thallus was detached by a careful and quick cut with a knife immediately above the substratum keeping physical disturbance at a minimum. After one minute of floating freely (treatment: 1 minute) the detached algae were enclosed in plastic bags. We used plastic bags which were open at both ends. The bags were unfolded in the water and each alga was slowly dragged into a bag. When the alga was inside the bag the ends were closed quickly and tied with rubber bands. No organisms were observed to escape while the algae were enclosed in the bags. Following the procedure applied in previous studies on the succession of the epifaunal communities on floating macroalgae (Edgar, 1987; Vásquez, 1993; Ingólfsson, 1998), individuals of $A$. nodosum were tethered with ropes and were left floating at the surface for two hours after detachment (treatment: 120 minutes). In contrast to previous studies, however, detached algae were not tethered to bottom weights but to attached conspecifics by thin ropes which were 3-4 $\mathrm{m}$ long. As a control, algae were placed in plastic bags before detachment. Control and 1 minute algae were collected at high tide. In order to perform the 120 minute treatment evenly around high tide, the algae were detached one hour before high tide and the experiment was finished 1 hour after high tide. For each treatment five individual algae served as replicates.

The plastic bags containing the algae and enclosed seawater were immediately transferred to the laboratories of Sandgerði Marine Station. There the mobile epifauna was carefully washed from the fronds with warm tap water and collected over a $0.5 \mathrm{~mm}$ sieve. After removal of excess water by shaking the fronds the algal wet weight (WW) was determined to $10 \mathrm{~g}$ accuracy. Algal wet weight ranged from $160 \mathrm{~g}$ to $1780 \mathrm{~g}$. Due to the large variability within the treatments, however, the average algal WW did not differ significantly between treatments (one-way ANOVA: $F_{2,12}=0.52$, $P=0.61$ ). All animals were identified to species level when possible. Numbers of epifaunal individuals were standardized to $1 \mathrm{~kg}$ of algal WW. As the number of species is likely to vary with sample size, diversity was calculated as expected number of species per 20 individuals (ES(20)) to account for variations in algal WW among replicates (Hurlbert, 1971). This parameter calculates the number of species that would be expected on larger samples that are scaled down to the size of the smallest sample taken.

To test if particular life history stages of associated species react differently to the detachment of their algal host we measured the size of each individual of the gastropod Littorina obtusata (Linnaeus, 1758). As the apex of the shell of L. obtusata is flattened and does not clearly protrude, we measured shell diameter instead of shell height. The maximum shell diameter as viewed from the apex was measured by a ruler to $0.5 \mathrm{~mm}$ accuracy and rounded down to the lower $0.5 \mathrm{~mm}$.

\section{Statistical analysis}

For all tests we considered the effect of the fixed factor 'time since algal detachment' with three levels (control, 1 minute and 120 minutes). We tested for treatment effects on the macro-zoobenthic assemblage using a PERMANOVA (permutation-based multivariate analysis of variance: Anderson, 2001, 2005) with 4999 permutations. Weight of the algal fronds served as covariate. Additionally, a canonical analysis of principal coordinates (CAP: Anderson, 2003; 
Anderson \& Willis, 2003) was performed. Multivariate tests were based on Bray-Curtis similarities (Legendre \& Legendre, 1998) of previously fourth root transformed data. A test of heterogeneity in dispersion was applied with the test of multivariate dispersion using the PERMDISP program by Anderson (2004) proving multivariate dispersion to be not significantly heterogeneous $(P>0.05)$. Treatment effects on the total number of individuals and the expected number of species $(\mathrm{E}(20)$ ) were evaluated by a one-way ANOVA followed by a Student-Newman-Keuls (SNK) post-hoc test.

The individuals of L. obtusata of each treatment were classified in three size-classes (o-4, 4.5-8 and 8.5-12 mm). Size-class distributions were compared among the treatments by a $3 \times 3$ contingency table.

\section{RESULTS}

A total of 16 taxa occurred on the thalli of Ascophyllum nodosum (Table 1). All of these taxa were present on attached as well as on detached algae. The only exception was the isopod Idotea baltica of which only a single individual was found on a detached thallus of the 120 minute-treatment. The most abundant species on

Table 1. Mean abundance $\pm \mathrm{SD}(\mathrm{N}=5)$ of mobile epifauna taxa on attached Ascophyllum nodosum (control) and on thalli that had been floating for 1 minute and for 120 minutes after detachment. Bold values denote significantly higher abundances evaluated by Student-Newman-Keuls test at $\alpha=0.05$ after one-way ANOVA. Other significant treatment effects were not detected on the species level.

\begin{tabular}{|c|c|c|c|}
\hline Taxon & Control & 1 minute & 120 minutes \\
\hline Plathelminthes & $7.9 \pm 6.6$ & $9.1 \pm 5.5$ & $6.7 \pm 3.1$ \\
\hline Nematoda & $2.8 \pm 4.3$ & $1.2 \pm 2.6$ & $1.5 \pm 2.0$ \\
\hline Nemertea & $3.2 \pm 3.1$ & $0.0 \pm 0.0$ & $0.6 \pm 1.4$ \\
\hline \multicolumn{4}{|l|}{ Gastropoda } \\
\hline $\begin{array}{l}\text { Lacuna vincta } \\
\qquad(\text { Montagu, 1803) }\end{array}$ & $1.2 \pm 2.7$ & $0.7 \pm 1.7$ & $0.0 \pm 0.0$ \\
\hline $\begin{array}{l}\text { Littorina littorea } \\
\quad(\text { Linnaeus, 1758) }\end{array}$ & $0.7 \pm 1.3$ & $0.0 \pm 0.0$ & $0.4 \pm 0.9$ \\
\hline $\begin{array}{l}\text { Littorina obtusata } \\
\quad \text { (Linnaeus, 1758) }\end{array}$ & $72.8 \pm 57.1$ & $86.9 \pm 22.7$ & $96.9 \pm 101.7$ \\
\hline $\begin{array}{l}\text { Nucella lapillus } \\
\quad \text { (Linnaeus, 1758) }\end{array}$ & $0.5 \pm 1.0$ & $0.0 \pm 0.0$ & $0.0 \pm 0.0$ \\
\hline Oligochaeta & $10.7 \pm 7.3$ & $40.5 \pm 51.4$ & $196.5 \pm 239.8$ \\
\hline \multicolumn{4}{|l|}{ Polychaeta } \\
\hline $\begin{array}{l}\text { Fabricia sabella } \\
\quad(\text { Ehrenberg, } 1836)\end{array}$ & $1.7 \pm 3.9$ & $0.0 \pm 0.0$ & $1.7 \pm 1.6$ \\
\hline \multicolumn{4}{|l|}{ Crustacea } \\
\hline $\begin{array}{l}\text { Calliopius } \\
\quad \text { laeviusculus } \\
\quad \text { (Krøyer, 1838) }\end{array}$ & $0.6 \pm 1.3$ & $0.0 \pm 0.0$ & $0.0 \pm 0.0$ \\
\hline $\begin{array}{l}\text { Gammarus stoerensis } \\
\quad \text { (Reid, 1938) }\end{array}$ & $10.3 \pm 8.1$ & $0.7 \pm 1.0$ & $0.3 \pm 0.7$ \\
\hline $\begin{array}{l}\text { Idotea baltica } \\
\qquad(\text { Pallas, 1772) }\end{array}$ & $0.0 \pm 0.0$ & $0.0 \pm 0.0$ & $0.4 \pm 0.9$ \\
\hline $\begin{array}{c}\text { Idotea granulosa } \\
\text { Rathke, } 1843\end{array}$ & $19.8 \pm 18.3$ & $5.1 \pm 5.8$ & $2.0 \pm 2.1$ \\
\hline Jaera sp. & $19.1 \pm 17.5$ & $0.0 \pm 0.0$ & $0.4 \pm 0.9$ \\
\hline Acari & $22.4 \pm 21.5$ & $2.8 \pm 2.1$ & $6.2 \pm 6.3$ \\
\hline \multicolumn{4}{|l|}{ Insecta } \\
\hline $\begin{array}{l}\text { Halocladius variabilis } \\
\quad \text { (Staeger, 1839) }\end{array}$ & $62.6 \pm 132.7$ & $8.8 \pm 16.2$ & $2.2 \pm 4.1$ \\
\hline
\end{tabular}

attached A. nodosum was the gastropod Littorina obtusata followed by larvae of the chironomid Halocladius variabilis. Littorina obtusata dominated also on detached fronds together with an unidentified oligochaete species.

The effect of algal detachment was significant at the community level (PERMANOVA $\mathrm{F}_{2,11}=2.33, P<0.05$ ) with the control treatment differing from the detachment treatments. Weight of algal fronds (covariable) did not significantly affect the composition of the faunal assemblage (PERMANOVA $\left.\mathrm{F}_{1,11}=1.50, P>0.05\right)$. Abundance was correlated with clump size only in the isopod Idotea granulosa in the control treatment $(\mathrm{r}=0.96, P<0.05)$. The ordination given by CAP showed that $73 \%$ of the replicates were correctly classified into their groups: all replicates of attached algae were grouped while the detached replicates were less clearly separated. Control and detachment treatments were clearly separated in the CAP plot (Figure 2): control replicates grouped in the positive section of the first canonical axis while the detached replicates grouped in the negative section of this axis. Most taxa correlated positively with the first canonical axis indicating a reduction in abundance after detachment. This was particularly evident for Jaera sp., Nemertea and Gammarus stoerensis that showed the highest correlations with the first canonical axis (Figure 2). These were the only taxa that were significantly less abundant on detached algae (Table 1). Other taxa such as H. variabilis, I. granulosa, and Acari also decreased strongly in abundance after detachment of the algae. Due to strong variations among replicates, however, these changes were statistically not significant.

Few taxa were negatively correlated with the first canonical axis, but the absolute values of the correlation were low $(\mathrm{r}<0.40)$. The average number of oligochaetes was four times higher on 1 minute algae than on control algae and 20 times higher on 120 minute algae. Similarly, the density of L. obtusata was 15 to $25 \%$ higher on detached algae. But again, for both species the differences were statistically not significant because of strong variations among the replicates.

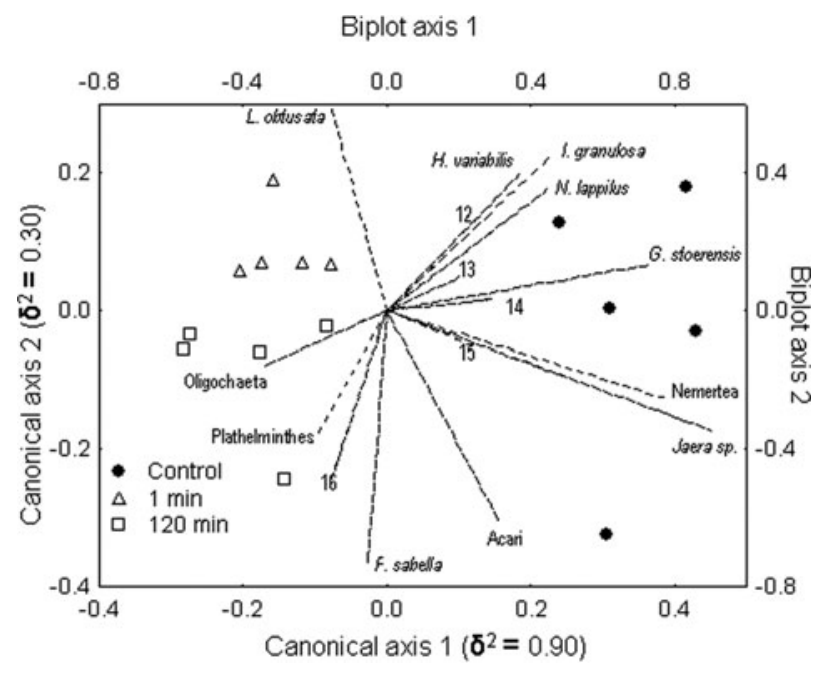

Fig. 2. Canonical analysis of principal coordinates (CAP) ordination with projection of individual taxa onto the ordination axes. The analysis was performed after Bray-Curtis distance of fourth root transformed data. CAP selected the first four principal coordinates that explained $79 \%$ of the total variation. Individual taxa with low correlation coefficients are given as numbers as follows: 12, Calliopius laeviusculus; 13, Lacuna vincta; 14, Littorina littorea; 15, Nematoda; 16, Idotea baltica. 
Due to the high number of oligochaetes on the floating algae, detachment and subsequent floating of A. nodosum had no significant effect on the total abundance of the epifaunal organisms (ANOVA: $\mathrm{F}_{2,12}=0.72, P>0.05$ ) (Figure 3). The expected number of species was reduced by algal detachment (ANOVA: $\mathrm{F}_{2,12}=6.69, P<0.05$ ) (Figure 4). ES(20) was higher on attached $A$. nodosum than on 1 minute algae (SNK test: $\mathrm{q}=3.94, P<0.05$ ) and on 120 minute algae (SNK test: $\mathrm{q}=4.87, P<0.05)$. ES(20) remained constant during subsequent floating of the algae (SNK test: $\mathrm{q}=0.92, P>0.05$ ).

The size of L. obtusata ranged from 0.5 to $12 \mathrm{~mm}$. In each treatment more than $90 \%$ of the individuals were $\leq 4 \mathrm{~mm}$ (Figure 5). The size-class distributions did not differ significantly among the treatments $\left(P=0.058, \chi^{2}=9.109, \mathrm{df}=4\right)$. The proportion of individuals with a shell diameter $>4 \mathrm{~mm}$, however, tended to decrease after algal detachment and during subsequent floating.

\section{DISCUSSIDN}

The detachment of benthic Ascophyllum nodosum was accompanied by a significant change in the community composition of the associated mobile epifauna. During the subsequent two hours of floating at the surface, however, the community composition remained stable. Although the total abundance of associated organisms was not affected by algal detachment the tendency towards lower abundances on detached algae, as previously observed by Kingsford \& Choat (1985), was evident in most taxa. These results confirm our hypothesis that substantial changes in the community of mobile organisms occur immediately after detachment of benthic algae.

\section{Emigration from detached algae}

The strongest decrease in abundance was observed in peracarid crustaceans such as Gammarus stoerensis, Jaera sp. and Idotea granulosa. The densities of these species dropped from some tens of individuals per $\mathrm{kg}$ algal WW to almost zero after detachment of the algae. Kingsford \& Choat (1985) observed a similar loss of phytal amphipods from macroalgae immediately after detachment. This observation was surprising since peracarids are among the most common rafting invertebrate species in the world's oceans

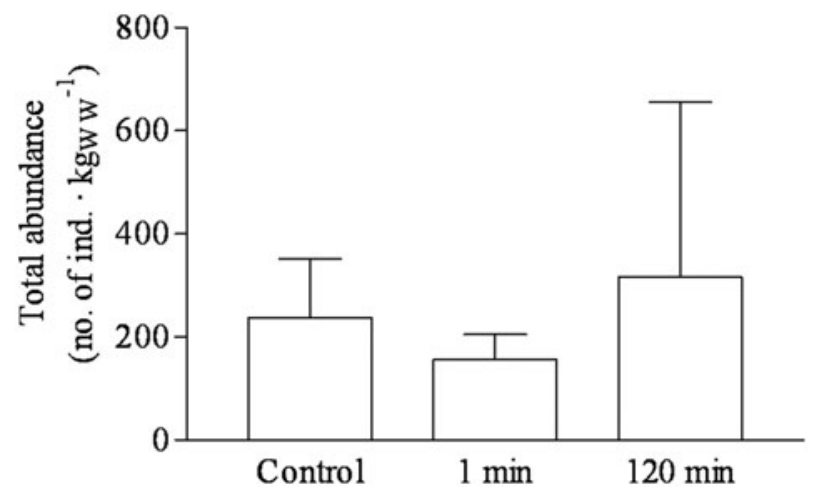

Fig. 3. Total abundance of mobile epifauna on attached Ascophyllum nodosum (control) and on thalli that had been floating for 1 minute and for 120 minutes after detachment. Error bars denote standard deviation $(\mathrm{N}=5)$.

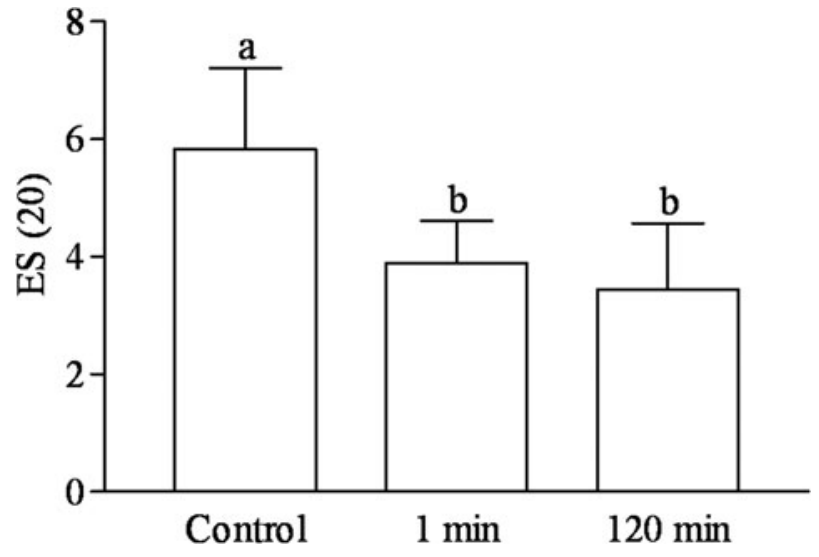

Fig. 4. Expected number of species (ES(20)) of mobile epifauna on attached Ascophyllum nodosum (control) and on thalli that had been floating for 1 minute and for 120 minutes after detachment. Different letters denote significant differences among treatments evaluated by Student-NewmanKeuls test at $\alpha=0.05$ after one-way ANOVA. Error bars denote standard deviation $(\mathrm{N}=5)$.

(Thiel \& Gutow, 2005b) indicating their high potential for persistence on floating items. The number of peracarids decreased drastically after detachment of the algae despite their high capability of clinging efficiently to their algal host (Dommasnes, 1968). We, therefore, assume that these animals leave the algae actively immediately after detachment. A similar rapid and strong reaction was observed for holdfastboring isopods Limnoria spp. in a Chilean kelp forest, which quickly abandoned their burrows after detachment of the holdfast from the substratum (Miranda \& Thiel, 2008).

Edgar (1987) expected that organisms on floating holdfasts of the giant kelp Macrocystis pyrifera experience greater water motion than on attached holdfasts. Accordingly, Thiel \& Gutow (2005b) suggested that some of the original inhabitants of the algae are lost from the community immediately after detachment because of their incapability of holding onto floating items. The majority of the taxa found in our study, however, have been repeatedly recorded as rafting organisms on macroalgae in coastal and offshore waters around Iceland (Ingólfsson, 1995, 1998), which confirms their general ability of clinging efficiently to floating algae. We, therefore, consider it unlikely that these animals are unable to hold onto detached algae especially under the calm weather conditions during the experimental period. Individuals of these taxa rather abandoned the algae actively after detachment, similar to the peracarids. Kingsford \& Choat (1985) assumed that a large

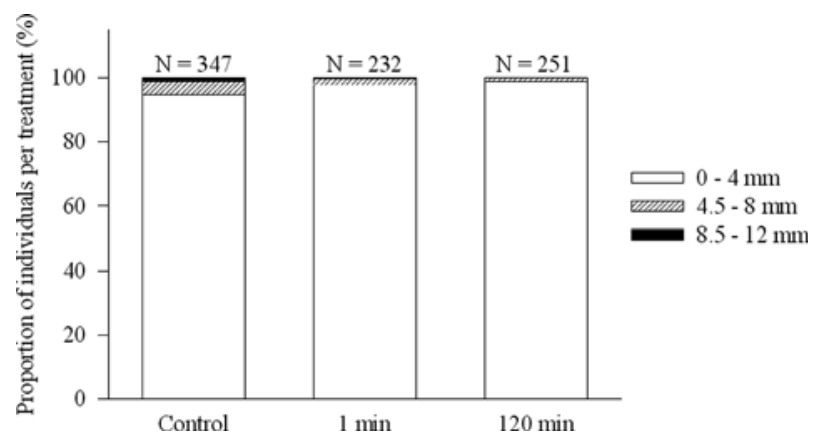

Fig. 5. Littorina obtusata. Proportions of individuals classified into one of three size-classes for each treatment. 
number of organisms will probably be removed from their host under stormy conditions when the algae tumble over the rocky substratum after detachment. Particularly large organisms such as gastropods will be shaken off from their algal host under rough conditions. Our comparison of the shell size-distributions of the gastropod L. obtusata showed a tendency towards lower proportions of larger individuals, which was, however, statistically not significant. The overall very small proportion of large individuals even on attached A. nodosum, however, did not allow for reliable conclusions concerning size-specific clinging capacities.

\section{Immigration onto floating algae}

It might be possible that the observed slight increase in the proportion of small L. obtusata on detached A. nodosum was simply an experimental artefact. The density of L. obtusata increased after algal detachment and was highest after two hours of floating. An even stronger increase in density on detached algae was observed for the oligochaetes. Juveniles of various gastropod species perform tidal migrations by entering the water column by the use of mucus threads (Martel \& Chia, 1991). It is unknown if small L. obtusata perform pelagic dispersal. Post-metamorphic drifting via mucus threats was, however, reported for the congener Littorina sitkana (Martel \& Chia, 1991). Similarly, benthic oligochaetes suspend in the water column and use tidal currents for migrations between intertidal and subtidal habitats (Nilsson et al., 2000). Suspended individuals might have been sieved out of the water column and become concentrated on the tethered algal fronds that were floating for one hour at the surface in the ebb tide.

\section{Causes and implications of rapid migration after algal detachment}

The exact signal, which induces the observed rapid reaction of the associated organisms is unclear. It is unlikely that the active escape from the detached plants was induced simply by the presence of a field investigator shadowing the algae like predatory fish or seabirds do. This effect should have been observed on attached algae as well. Phytal animals avoid exposure to visually hunting predators by hiding on their algal host during daytime (Taylor, 1998). Migration is, thus, unlikely to be induced by the presence of a potential predator.

Phytal organisms might be deterred by chemicals released by the algae after detachment. Indeed, wounded $A$. nodosum releases chemicals that attract predators. The release of such infochemicals is, however, induced by grazing herbivores and not by artificial damage of the alga (Coleman et al., 2007).

The epifaunal organisms may perceive changes in their physical environment after the detachment of the benthic macroalgae. Due to the shallowness of the study site (i.e. $\sim 1.5 \mathrm{~m}$ depth) the changes in light intensity and pressure during the ascent of the algae to the surface seem negligible. The altered movement pattern of the algae after detachment and the changed drag forces might form a signal of habitat modification that induces the reaction of the animals.

By escaping from the detached algae the animals avoid displacement from the structurally complex phytal habitat that provides efficient shelter from visually hunting predators (Nelson, 1979). The isolation of a detached alga from the benthic assemblage will affect the structural complexity of the floating habitat and reduce the protective efficiency. Many floating macroalgae end up on nearby beaches shortly after detachment (Harrold \& Lisin, 1989). Therefore, Miranda \& Thiel (2008) suggested that rapid emigration from detached macroalgae reduces the risk for associated organisms to become deposited on the shore.

For most species the decrease in abundance after detachment of the algal host was statistically not significant indicating that a substantial number of individuals remain associated with floating algae. Obviously conspecific individuals differ in their readiness for active migration. Differential migratory activity among life history stages has been described for various species including peracarids (Johnson \& Menzies, 1956), bivalves (Lane et al., 1985), and gastropods (Martel \& Chia, 1991). The individuals that hold onto their algal raft after detachment have a considerable chance of being carried out of the local kelp forest and enter large scale offshore currents. Low migratory activity can, thus, increase the probability for long distance dispersal. Efficient rafting dispersal can result in natural range expansion (Johannesson, 1988), colonization of new areas (Ó Foighil et al., 1999), and connectivity among local populations allowing for regional persistence of species through metapopulation effects (Thiel \& Haye, 2006).

In conclusion, our experiments showed that the moment of detachment of benthic macroalgae has a substantial effect on the composition of the epifaunal community and, thus, the future succession of the rafting community.

\section{ACKNDWLEDGEMENTS}

This study was funded by a grant of the EU-IHP programme 'Access to Research Infrastructures' to R.S. We gratefully acknowledge the support of G.V. Helgason and the staff from Sandgerði Marine Centre. Helpful comments of an anonymous referee and especially Martin Thiel improved the manuscript.

\section{REFERENCES}

Anderson M. (2001) A new method for non-parametric multivariate analysis. Austral Ecology 26, 32-46.

Anderson M. (2003) CAP: a FORTRAN computer program for canonical analysis of principal coordinates. Department of Statistics, University of Aukland, New Zealand.

Anderson M. (2004) PERMDISP: a FORTRAN computer program for permutational analysis of multivariate dispersions (for any two-factor ANOVA design) using permutation tests. Department of Statistics, University of Auckland, New Zealand.

Anderson M. (2005) PERMANOVA: a FORTRAN computer program for permutational multivariate analysis of variance. Department of Statistics, University of Aukland, New Zealand.

Anderson M. and Willis T. (2003) Canonical analysis of principal coordinates: a useful method of constrained ordination for ecology. Ecology $84,511-525$.

Anonymous (1993) Sjávarföll við Ísland 1994. Sjómælingar Íslands 41, $31 \mathrm{pp}$.

Cheng L. (1975) Marine pleuston-animals at the sea-air interface. Oceanography and Marine Biology: an Annual Review 13, 181-212. 
Coleman R.A., Ramchunder S.J., Davies K.M., Moody A.J. and Foggo A. (2007) Herbivore-induced infochemicals influence foraging behaviour in two intertidal predators. Oecologia 151, 454-463.

Dommasnes A. (1968) Variations in the meiofauna of Corallina officinalis L. with wave exposure. Sarsia 34, 117-124.

Duggins D., Eckman J.E., Siddon C.E. and Klinger T. (2001) Interactive roles of mesograzers and current flow in survival of kelps. Marine Ecology Progress Series 223, 143-155.

Edgar G.J. (1987) Dispersal of faunal and floral propagules associated with drifting Macrocystis pyrifera plants. Marine Biology 95, 599-610.

Espinosa F. and Guerra-García J.M. (2005) Algae, macrofaunal assemblages and temperature: a quantitative approach to intertidal ecosystems of Iceland. Helgoland Marine Research 59, 273-285.

Harrold C. and Lisin S. (1989) Radio-tracking rafts of giant kelp: local production and regional transport. Journal of Experimental Marine Biology and Ecology 130, 237-251.

Hobday A.J. (2000) Persistence and transport of fauna on drifting kelp (Macrocystis pyrifera (L.) C. Agardh) rafts in the Southern California Bight. Journal of Experimental Marine Biology and Ecology 253, 75-96.

Hurlbert S.H. (1971) The nonconcept of species diversity: a critique and alternative parameters. Ecology 52, 577-586.

Ingólfsson A. (1995) Floating clumps of seaweed around Iceland: natural microcosms and a means of dispersal for shore fauna. Marine Biology $122,13-21$.

Ingólfsson A. (1996) The distribution of intertidal macrofauna on the coasts of Iceland in relation to temperature. Sarsia 81, 29-44.

Ingólfsson A. (1998) Dynamics of macrofaunal communities of floating seaweed clumps off western Iceland: a study of patches on the surface of the sea. Journal of Experimental Marine Biology and Ecology 231, 119-137.

Johannesson K. (1988) The paradox of Rockall: why is a brooding gastropod (Littorina saxatilis) more widespread than one having a planktonic larval dispersal stage (L. littorea)? Marine Biology 99, 507-513.

Johnson M.W. and Menzies R.J. (1956) The migratory habits of the marine gribble Limnoria tripunctata Menzies in San Diego Harbor, California. Biological Bulletin. Marine Biological Laboratory, Woods Hole 110, 54-68.

Kingsford M.J. and Choat J.H. (1985) The fauna associated with drift algae captured with a plankton-mesh purse seine net. Limnology and Oceanography 30, 618-630.

Lane D.J.W., Beaumont A.R. and Hunter J.R. (1985) Byssus drifting and the drifting threads of the young post-larval mussel Mytilus edulis. Marine Biology 84, 301-308.

Legendre P. and Legendre L. (1998) Numerical ecology. 2nd edition. Amsterdam: Elsevier.

Martel A. and Chia F.S. (1991) Drifting and dispersal of small bivalves and gastropods with direct development. Journal of Experimental Marine Biology and Ecology 150, 131-147.

Miranda L. and Thiel M. (2008) Active and passive migration in boring isopods Limnoria spp. (Crustacea, Peracarida) from kelp holdfasts. Journal of Sea Research 60, 176-183.

Nelson W.G. (1979) Experimental studies of selective predation on amphipods: consequences for amphipod distribution and abundance. Journal of Experimental Marine Biology and Ecology 38, 225-245.
Nilsson P.G., Levinton J.S. and Kurdziel J.P. (2000) Migration of a marine oligochaete: induction of dispersal and microhabitat choice. Marine Ecology Progress Series 207, 89-96.

Ó Foighil D., Marshall B.A., Hilbish T.J. and Pino M.A. (1999) Trans-Pacific range extension by rafting is inferred for the flat oyster Ostrea chilensis. Biological Bulletin. Marine Biological Laboratory. Woods Hole 196, 122-126.

Seymour R.J., Tegner M.J., Dayton P.K. and Parnell P.E. (1989) Storm wave induced mortality of giant kelp, Macrocystis pyrifera, in southern California. Estuarine, Coastal and Shelf Science 28, 277-292.

Stoner A.W. and Greening H.S. (1984) Geographic variation in the macrofaunal associates of pelagic Sargassum and some biogeographic implications. Marine Ecology Progress Series 20, 185-192.

Takeuchi I. and Sawamoto S. (1998) Distribution of caprellid amphipods (Crustacea) in the western North Pacific based on the CSK International Zooplankton Collection. Plankton Biology and Ecology $45,225-230$.

Taylor R.B. (1998) Short-term dynamics of a seaweed epifaunal assemblage. Journal of Experimental Marine Biology and Ecology 227, 67-82.

Thiel M. and Gutow L. (2005a) The ecology of rafting in the marine environment. I. The floating substrata. Oceanography and Marine Biology: an Annual Review 42, 181-263.

Thiel M. and Gutow L. (2005b) The ecology of rafting in the marine environment. II. The rafting organisms and community. Oceanography and Marine Biology: an Annual Review 43, 279-418.

Thiel M. and Haye P.A. (2006) The ecology of rafting in the marine environment. III. Biogeographical and evolutionary consequences. Oceanography and Marine Biology: an Annual Review 44, 323-429.

Thomsen M.S., Wernberg T. and Kendrick G.A. (2004) The effect of thallus size, life stage, aggregation, wave exposure and substratum conditions on the forces required to break or dislodge the small kelp Ecklonia radiata. Botanica Marina 47, 454-460.

Tsikhon-Lukanina E.A., Reznichenko O.G. and Nikolaeva G.G. (2001) Ecology of invertebrates on the oceanic floating substrata in the Northwest Pacific Ocean. Oceanology 41, 525-530.

Vandendriessche S., Messiaen M., O'Flynn S., Vincx M. and Degraer S. (2007a) Hiding and feeding in floating seaweed: floating seaweed clumps as possible refuges or feeding grounds for fishes. Estuarine, Coastal and Shelf Science 71, 691-703.

Vandendriessche S., Stienen E.W.M., Vincx M. and Degraer S. (2007b) Seabirds foraging at floating seaweeds in the Northeast Atlantic. Ardea $95,289-298$.

and

Vásquez J.A. (1993) Effects on the animal community of dislodgement of holdfasts of Macrocystis pyrifera. Pacific Science 47, 180-184.

\section{Correspondence should be addressed to:}

L. Gutow

Alfred Wegener Institute for Polar and Marine Research

Box 1201 61, 27515 Bremerhaven, Germany

email: Lars.Gutow@awi.de 